\title{
ROZWAŻANIA NAD KONCEPCJĄ HISTORII JĘZYKOZNAWSTWA POLSKIEGO
}

Słowa klucze: historia polskiego językoznawstwa, historia nauki, językoznawstwo stosowane, glottodydaktyka polonistyczna, język polski jako obcy, odziedziczony i drugi

Keywords: history of Polish linguistics, history of science, applied linguistics, teaching Polish, Polish as a foreign language, Polish as a heritage language, Polish as a second language

\section{Wprowadzenie}

Od kilku lat namawiałem Prof. Mirosława Skarżyńskiego do napisania artykułu, w którym przedstawiłby on swoją koncepcję przyszłej historii językoznawstwa polskiego. Wiadomo było bowiem, że historia językoznawstwa interesuje go bardzo od czasu, kiedy jego prace i studia związane ze słowotwórstwem języka polskiego stały się mniej intensywne. O zmianie zainteresowań świadczyła najpierw jego monografia habilitacyjna Części mowy i ich kategorie w gramatykach polskich XIX i XX wieku (1817-1938) (Skarżyński 1994). Praca ta została później rozszerzona i wydana pt. W kręgu gramatyk polskich XIX i XX wieku (Skarżyński 2001). Już po uruchomieniu półrocznika „LingVaria” jego zainteresowania historią językoznawstwa polskiego potwierdzały wydawane w „Bibliotece LingVariów” tomy korespondencji wybitnych językoznawców polskich: Jana Baudouina de Courtenay, Henryka Ułaszyna, Jana Łosia, Jana Rozwadowskiego, a także Kazimierza Nitscha i Antoniny Obrębskiej-Jabłońskiej (Czelakowska, Rak 2019: 8; Czelakowska 2020). To były materiały do historii językoznawstwa, ale bardzo ważne ze względu na wielką rolę, którą każdy z uczonych odegrał w polskim językoznawstwie. Dobrze się stało, że wydania te 
zostały dostrzeżone i wykorzystane przez lingwistów, o czym świadczy artykuł Elżbiety Sękowskiej List jako źródło do historii polskiego językoznawstwa (w druku). Jakie mogłyby być efekty prowadzonych badań, M. Skarżyński pokazał w kilku tekstach, z których ostatnim jest artykuł Geneza i początki Studium Słowiańskiego UJ (Skarżyński 2019).

Wszyscy znający go bliżej wiedzieli o jego zainteresowaniach historycznych, trwających przez lata, wiedzieli także np. o tym, że przy wyborze filologii polskiej jako kierunku studiów wahał się, gdyż równie atrakcyjne wydawało mu się studiowanie historii. W studiach historycznych szczególnie pociągały go badania archiwalne, w czasie których zdobywa się konkretną dokumentację, która pozwala opisać autentyczny przebieg zdarzeń albo też dokonać korekty w opisach już istniejących. We wspomnianym artykule o genezie i początkach Studium Słowiańskiego UJ pokazywał, że obok celów naukowych równie ważne były cele polityczne, wyznaczane przez Ministerstwo Wyznań Religijnych i Oświecenia Publicznego oraz Ministerstwo Spraw Zagranicznych.

Zachęcając go do opracowania koncepcji przyszłej historii językoznawstwa polskiego, byłem przekonany, że opracowanie takiej koncepcji pomogłoby mu w organizacji prac przygotowawczych, stanowiłoby punkt odniesienia $\mathrm{w}$ trakcie prac nad samą historią językoznawstwa, gdyby zaś z jakiegoś powodu nie doszło do realizacji tego pomysłu, koncepcja ta mogłaby służyć innym osobom jako ważny punkt odniesienia. Muszę przyznać, że moja argumentacja nie zdała się na nic, ponieważ prof. M. Skarżyński widocznie nie miał zamiaru pisać takiej koncepcji. Zwykle odpowiadał, że jest bardzo dużo konkretnych prac do wykonania przed przystąpieniem do opracowywania koncepcji przyszłej historii językoznawstwa. Te prace to była publikacja poszczególnych tomów korespondencji wybitnych językoznawców oraz innych materiałów związanych $\mathrm{z}$ ich działalnością. Można by powiedzieć, że znajdował się w nich zbiór szczegółów, w którym prof. M. Skarżyński widział historię ogółu, czyli historię językoznawstwa polskiego.

Celem mojego artykułu jest wskazanie, że początki językoznawstwa polskiego należy datować na okres wcześniejszy, niż zaproponował to Stanisław Urbańczyk w książce Dwieście lat polskiego językoznawstwa (1751-1950) (1993). Drugim celem jest próba odpowiedzi na istotne pytanie, kto powinien się zajmować historią językoznawstwa polskiego: lingwiści czy historycy nauki. Trzecim zaś - zwrócenie uwagi na fakt, że historia językoznawstwa polskiego stanie się bogatsza, kiedy konsekwentnie uwzględnimy w niej historię nauczania polszczyzny jako języka obcego.

\section{Początki językoznawstwa polskiego}

2.1. W tej sytuacji chciałbym wrócić do koncepcji historii językoznawstwa polskiego i przedstawić własny punkt widzenia, nawiązując do opublikowanego dwa lata temu 
artykułu Gramatyka języka polskiego Statoriusa ukazała się 450 lat temu. Refleksje o jej znaczeniu dla historii polskiego językoznawstwa (Miodunka 2018). Ważnym powodem napisania tamtej pracy był fakt, że Francuz, Piotr Statorius, jest znany polonistom francuskim, którzy uważają, że jego gramatyka języka polskiego (Statorius 1568/1980) stanowi pierwsze ogniwo kontaktów językowych francusko-polskich, bardzo ważne do dziś dla polonistów francuskich, ale z natury rzeczy bardzo ważne także dla językoznawstwa polskiego. Ponieważ moim zdaniem brakowało w Polsce artykułu, który mógłby być odpowiednikiem pracy Etienne’a Decaux Il y a quatre cents ans paraissait sous la signature d'un Français, la première grammaire polonaise (1968), chciałem napisać artykuł przypominający tamto ważne wydarzenie, przy okazji przedstawiając obecny punkt widzenia i wykorzystując wszystkie dotychczasowe badania. W rezultacie przeprowadzonych studiów powstał artykuł pokazujący znaczenie gramatyki P. Statoriusa. Kończył się on następującym stwierdzeniem:

szersze spojrzenie na gramatykę Statoriusa-Stojeńskiego z uwzględnieniem historii nauki polskiej oraz historii językoznawstwa ogólnego rzuca nowe światło na znaczenie tej gramatyki. Polonicae grammatices institutio jawi się odtąd jako pierwsza gramatyka języka polskiego należąca do wielkiego, europejskiego ruchu opisu języków nowożytnych, języków ważnych narodów europejskich. Co więcej, gramatyka ta wraz ze słownikiem Mączyńskiego wyznacza na nowo początki językoznawstwa polskiego. Gdyby przyjąć takie rozumowanie, należałoby przesunąć początki polskiego językoznawstwa prawie o dwieście lat do przodu: z roku 1751 na lata 6o. wieku XVI, pamiętając o wcześniejszych zasługach takich autorów jak Jakub Parkoszowic czy Stanisław Zaborowski (Miodunka 2018: 22).

2.2. Zdobyte wtedy doświadczenia postanowiłem wykorzystać obecnie, przedstawiając wstępną koncepcję historii językoznawstwa polskiego. Trzeba pamiętać o tym, że podany w artykule rok 1751 stanowił nawiązanie do monografii S. Urbańczyka Dwieście lat polskiego językoznawstwa (1751-1950) (1993). Jak wynika z dat podanych w tytule, pisząc swoją historię językoznawstwa polskiego, Urbańczyk rozpoczynał ją w połowie XVIII w., konkretnie w roku 1751. Autor brał jednak pod uwagę możliwość zakwestionowania daty początkowej, pisząc tak:

Można by ją zastąpić np. datą elekcji Stanisława Augusta (1764) lub datą powstania Komisji Edukacji Narodowej (1773). Jeżeli nawet popełniłem błąd, przyjmując za granicę rok 1751, to jednak nie sądzę, aby sprawa na tym ucierpiała (ibid.: VI).

Z cytowanego tu fragmentu wynika, że S. Urbańczyk wiązał początki językoznawstwa polskiego z epoką oświecenia, konkretnie z ważnymi datami politycznymi tej epoki. Uczony zwracał wielką uwagę na działania reformatorów języka, nawołujących do zmian stylistycznych w polskiej prozie, a także w retoryce. Ich celem było wyeliminowanie makaronizmów oraz barokowej konstrukcji zdań, a także ograniczenie posługiwania się łaciną na rzecz języka polskiego. Dla przeprowadzanej tu argumentacji ważny jest fakt, że Urbańczyk wiązał początki językoznawstwa 
polskiego z oświeceniem, a nie $\mathrm{z}$ okresem renesansu, kiedy została opublikowana m.in. pierwsza gramatyka polszczyzny, napisana przez P. Statoriusa. Z tego względu warto zwrócić uwagę na fakt, że w drugim wydaniu Encyklopedii języka polskiego pod red. S. Urbańczyka (EJP) pojawił się nowy artykuł pt. Językoznawstwo polonistyczne - historia, którego autorem był redaktor Encyklopedii. W tym dość obszernym, bo czterostronicowym opracowaniu, wiązał on początki językoznawstwa w Polsce z nauczaniem łaciny i tłumaczeniem tekstów łacińskich w szkołach takich jak np. szkoła przy katedrze wawelskiej w Krakowie czy też w Akademii Krakowskiej. W tym samym tekście znalazł się paragraf poświęcony gramatyce P. Statoriusa-Stojeńskiego, który brzmiał następująco:

W r. 1568 wyszła pierwsza gramatyka języka polskiego, napisana przez Piotra Stojeńskiego (Statoriusza). Jak wiele późniejszych, przeznaczona była dla cudzoziemców. Opisał on, wcale szczegółowo, ówczesną wzorową polszczyznę, odwołując się często do przykładów czerpanych z pism Reja, Kochanowskiego i innych. Na tej gramatyce wzorowali się autorzy późniejsi, jak Volckmar, Roter, Meniński, Malicki (EJP: 147).

Jak widać, Urbańczyk odnotował wydanie pierwszej gramatyki języka polskiego, a także jej znaczny wpływ na gramatyki autorów późniejszych. Ciekawe jest natomiast to, że nie nadawał gramatyce Statoriusa jakiegoś specjalnego znaczenia $\mathrm{w}$ historii językoznawstwa polonistycznego. Ponieważ przygotowywanie do druku drugiego wydania Encyklopedii języka polskiego zbiegało się w czasie z końcowymi pracami nad redakcją Dwustu lat polskiego językoznawstwa, trudno zrozumieć, dlaczego w tym ujęciu językoznawstwo polskie zaczynało się dopiero w roku 1751, ale w historii językoznawstwa polonistycznego został uwzględniony wiek XVI, a nawet XV, gdyż autor wspomniał traktat ortograficzny Jakuba Parkoszowica z 1440 r., podkreślając fakt, że omówiono w nim opozycję samogłosek długich i krótkich oraz spółgłosek palatalnych i niepalatalnych.

\section{Europejskie językoznawstwa materiałowe w XVI w.}

3.1. Stwierdzenie tej rozbieżności skłoniło mnie wtedy do pokazania gramatyki Statoriusa na tle językoznawstwa europejskiego XVI w. Dlatego sięgnąłem do dzieła Adama Heinza Dzieje językoznawstwa w zarysie (1978). Heinz podkreślał, że odrodzeniowe prace $z$ zakresu językoznawstwa można podzielić na gramatyki języków nowożytnych, należące do językoznawstwa materiałowego, oraz próby porównywania języków i opracowywania ich klasyfikacji, należące do językoznawstwa teoretycznego. Uczony wymieniał tu dla przykładu publikowane w XVI w. pierwsze gramatyki takich języków europejskich, jak włoski, hiszpański, kataloński, portugalski, francuski, bretoński, walijski, angielski, niemiecki, także węgierski i baskijski. Tu wspomniał także gramatykę P. Statoriusa oraz Lexicon latino-polonicum... Jana 
Mączyńskiego z 1564 r. Heinz podkreślał, że metody sprawdzone w trakcie opisu języków klasycznych, martwych, zaczęto stosować również do opisu języków żywych, nowożytnych. Przy okazji rozwiązywano wiele problemów szczegółowych związanych np. $z$ ustalaniem zasobu głosek w danym języku i ich znaków graficznych. Autor wskazywał również, że wszystkie te opracowania gramatyk i słownictwa języków europejskich miały charakter podręcznikowy, praktyczny. Warto o tym pamiętać, ponieważ Statorius także napisał swoją gramatykę dla obcokrajowców, których wielu przebywało wtedy w Krakowie, ale nie znali oni języka polskiego, a możliwe, że chcieli się go nauczyć.

3.2. Aby pokazać, jak mogła się różnić realizacja zadania opisywania konkretnych języków europejskich, odwołałem się do historii francuszczyzny, szczególnie do renesansowych gramatyk tego języka. Informacje o stosunkowo dużej liczbie opracowań gramatyki języka francuskiego kończyły się następującym stwierdzeniem:

Duża liczba opracowań języka francuskiego przygotowywanych poza Francją świadczyła o wielkiej mocy i atrakcyjności tego języka, który na kilka wieków miał stać się językiem międzynarodowym ludzi wykształconych i intelektualistów, także arystokracji i szlachty. [...] Kończąc ten przegląd opracowań języka francuskiego, można powiedzieć, że w pierwszych latach XVI w. nie było jeszcze gramatyki języka francuskiego w ścisłym słowa tego znaczeniu, natomiast kiedy wiek ten dobiegał końca, było już wiele podręczników gramatyki francuskiej wydanych po łacinie, francusku i w językach obcych we Francji, jak i poza jej granicami (Miodunka 2018: 18).

Sytuacja w Polsce pod tym względem była zupełnie odmienna: w XVI w. ukazały się tylko dwie gramatyki polszczyzny. Po gramatyce Statoriusa, wydanej w 1568 r., opublikowano tylko jedną gramatykę Mikołaja Volckmara, zatytułowaną Compendium linguae polonicae... (1594). Jej autor był Niemcem z Hesji, działającym w Gdańsku jako nauczyciel języka polskiego i łaciny. Compendium... M. Volckmara miało cztery wydania w ciągu 50 lat, co świadczyło o dużej popularności tej gramatyki. Było też wykorzystywane przez wielu autorów późniejszych gramatyk polszczyzny. Badający Compendium... Przemysław Zwoliński obliczył, że w swoim dziele Volckmar „zapożyczy”” od Statoriusa około 90\% informacji, i używając pojęcia w XVI w. nieznanego, nazwał Volckmara „plagiatorem” (Zwoliński 1956: 310-321). Z tak radykalną opinią nie zgodziła się Regina Jefimow, która po analizie porównawczej obu gramatyk wyraziła taką opinię:

Volckmar rzeczywiście oparł się na podręczniku Stojeńskiego, dziele pionierskim i samodzielnym: przejął od niego ogólny układ treści gramatyki i wykorzystał materiał przykładowy. Niczego jednak nie przyjmował bezkrytycznie. Materiał Stojeńskiego starał się uporządkować, dokonał przemyślanego wyboru przykładów, typowych dla danego zjawiska językowego. Chociaż obie gramatyki dzieli okres jednego tylko pokolenia, język opracowywany przez Volckmara jest pod wieloma względami 
nowszy niż język Stojeńskiego. [...] Gramatyka Volckmara jest też lepsza ze względów dydaktycznych przez swoją przejrzystość, zwartość, uporządkowanie materiału, konsekwentny układ graficzny (Jefimow 1963: 220).

Wydane w XVI w. gramatyki języków nowożytnych zalicza się zwykle do lingwistyki materiałowej, ponieważ dokumentowały one istnienie wielu języków, którymi się wcześniej nie zajmowano, opisywały ich wymowę i grafię oraz elementy gramatyki, odwołując się do przykładów zdań i tekstów. Pierwsza gramatyka polska, zatytułowana Polonicae grammatices institutio, była pod tym względem jedną z wielu tworzonych wtedy gramatyk europejskich. Sam Statorius zdawał sobie sprawę, że napisał pierwszą gramatykę polszczyzny. Wyraził to w dedykacji dla Andrzeja Dudycza, mieszkającego w Krakowie humanisty węgierskiego, pisząc tak:

wkroczywszy jako pierwszy na trudną drogę pisania gramatyki, swoją niedorzeczną i surową pisaniną zmobilizowałem do pisania innych, którzy świetnie temu zadaniu sprostają, wytrącając ich z bezczynności i gnuśności (cyt. i tłum z łac. za: https:// gramatyki.uw.edu.pl/book/168).

Jego przekonanie, że Polonicae grammatices institutio będzie miała kontynuatorów i naśladowców, sprawdziło się całkowicie, czego dowiodła R. Jefimow, która badała wydane w Gdańsku gramatyki języka polskiego M. Volckmara (wydanie Z 1646 r.), Jakuba Gadebuscha (1621 r.), Franciszka Mesgnien-Menińskiego (1649 r.), Wacława Gersona Brożka (1664 r.) i Zygmunta Kontzewitza-Kotzera (1668 r.). Po dokonaniu analizy opublikowanych w XVII w. gramatyk polskich uznała je za drugi etap w historii opisu polszczyzny, za etap pierwszy uważając gramatykę Statoriusa-Stojeńskiego (Jefimow 1970: 175).

\section{Początki europejskiego językoznawstwa porównawczego w XVI w.}

4.1. Jeśli chodzi o prace polegające na porównywaniu języków oraz opracowywaniu ich klasyfikacji, to miały one dwojaki charakter: polegały na czysto zewnętrznych zestawieniach natury słownikowej lub tekstowej różnych języków albo na próbach klasyfikacji genealogicznej i typologicznej języków (Heinz 1978: 91). Jako przykład zestawiania i porównywania słownictwa różnych języków podaje się często słynny słownik Włocha, Ambrogio Calepino, który wydał w 1502 r. równoległy słownik siedmiu języków Dictionarium septem linguarum. Słownik ten odniósł wielki sukces i cieszył się rozgłosem, dlatego kolejne wydania były wzbogacane o nowe języki. W wyniku tych uzupełnień wydanie szwajcarskie słownika z roku 1590 zawierało 11 języków, w tym język polski, co świadczyło o wysokiej pozycji ówczesnej polszczyzny w Europie (Klemensiewicz 1974: 354). 
4.2. Jako przykład zróżnicowania językowego za pomocą tekstów podaje się często dzieło szwajcarskiego lekarza i filologa, Conrada Gesnera. Gesner przygotował próbki 22 języków, wychodząc od tłumaczonego tekstu modlitwy Pater noster. Znaczenie cytowanych tekstów było zawsze takie samo, natomiast różniły się one formą językową, słownictwem i gramatyką. Jego dzieło wydane w 1558 r. nosiło tytuł Mithridates. De differentiis linguarum tum veterum, tum quae hodie apud diversas nationes in toto orbe terrarum in usu sunt, observationes. Warto wyjaśnić, że pierwsze słowo tytułu, Mithridates, to nazwisko króla Pontu z II-I w. p.n.e., sławnego dzięki temu, że miał znać 22 języki podległych mu ludów, co wówczas stanowiło sensację, ale także dziś stanowiłoby przedmiot chluby. Wśród opisywanych przez Gesnera języków znalazły się języki słowiańskie, które zostały omówione w rozdziale drugim De Illirica sive Sarmatica lingua oraz De Moschorum vel Mosconitarum lingua. Trzeba tu zaznaczyć, że języki słowiańskie uwzględnił w swej typologii po raz pierwszy Theodore Bibliander w 1548 r., natomiast Gesner opisał język rosyjski i jego dialekty obok innych języków słowiańskich.

Bibliander to zhellenizowane nazwisko niemieckiego teologa, filologa i orientalisty Theodora Buchmanna (1504?-1564), który opublikował w połowie XVI w. swoje dzieło pt. De ratione communi omnium linguarum et litterarum commentarius (1548). Warto dodać, że Bibliander eksponował w swym opisie język polski, ponieważ jego informatorem w zakresie języków słowiańskich był przyszły polski leksykograf, J. Mączyński, studiujący wtedy u niego w Zurychu. Bibliander pisał o swym studencie bardzo pochlebnie, podkreślając jego znakomite wykształcenie i znajomość wielu języków (Zwoliński 1972: 341-342).

Przemysław Zwoliński uważał Gesnera za ucznia, młodszego kolegę i kontynuatora dzieła Bibliandra, natomiast ich obu za filologów, którzy w swoich pracach zapoczątkowali komparatystykę slawistyczną. Zdaniem Zwolińskiego rok publikacji dzieła Bibliandra (1548) to data rozpoczynająca badania w zakresie komparatystyki slawistycznej (Zwoliński 1972), która obecnie ma tradycję liczącą 472 lata.

4.3. Podsumowując sytuację językoznawstwa europejskiego $w$ dobie renesansu i humanizmu, Adam Heinz pisał o zasadniczym przełomie w lingwistyce spowodowanym równouprawnieniem wszystkich języków w obliczu nauki, które zaowocowało opisami nowożytnych języków, najpierw Starego Świata, a potem też Nowego Świata. Leksykalne i gramatyczne ich opisy miały charakter porównawczy z tego względu, że ich autorzy wykorzystywali model opisu łaciny, co w naturalny sposób prowadziło do porównywania np. gramatyki polskiej z gramatyką łacińską przez P. Statoriusa (Heinz 1978: 95).

Na zakończenie tej części rozważań warto jeszcze raz podkreślić, że gramatyka Statoriusa należała do wielkiego europejskiego ruchu opisu języków nowożytnych, języków ważnych narodów europejskich. Taka ocena tej gramatyki powoduje, że 
może ona wraz ze słownikiem J. Mączyńskiego wyznaczać początki językoznawstwa polskiego w połowie XVI w.

\section{Językoznawstwo polskie w pracach z zakresu historii nauki}

5.1. W swoim artykule sprzed dwu lat odwołuję się także do Historii nauki polskiej pod redakcją Bogdana Suchodolskiego (1970a). W obszernym, bo liczącym ponad 60 stron, wstępie do tego dzieła, zatytułowanym O powszechnej i polskiej historii $n a u k i$, B. Suchodolski omówił nowoczesną koncepcję powszechnej historii nauki, potem historię nauki w jednym kraju, na przykładzie nauki w Polsce, wreszcie miejsce nauki w kulturze Polski dawnej (Suchodolski 1970b: VII-LXXI). Autorami historii nauki w poszczególnych epokach zostali historycy, uważani za wybitnych znawców danego okresu. Aby jednak nie pominąć faktów ważnych dla konkretnej dyscypliny, „zaproszono do współpracy przedstawicieli różnych dziedzin wiedzy, którzy wyłącznie dla »Historii nauki polskiej« napisali referaty cząstkowe z historii swej specjalności” (ibid.: V).

W tomie pierwszym tego dzieła znalazło się opracowanie Pawła Rybickiego poświęcone nauce polskiej w okresie renesansu. Rybicki zawarł w nim m.in. takie stwierdzenie: „Mączyński i Statorius byli pierwszymi przedstawicielami pracy naukowej nad językiem polskim" (Rybicki 1970: 371), upatrując w ich dziełach początków polskiego językoznawstwa. Na Historię nauki polskiej zwracam uwagę, ponieważ jest to dzieło bardzo starannie przygotowane, które moim zdaniem musi być brane pod uwagę podczas pisania przyszłej historii językoznawstwa polskiego. Historia nauki polskiej była pisana nie przez językoznawców, ale przez historyków, którzy uwzględniali istniejące prace językoznawcze i oceniali ogólnie rozwój filologii polskiej w poszczególnych epokach. Oczywiście, mogły im się zdarzyć oceny przesadzone i mylne, ale one mogą być przecież poprawione w trakcie pisania opracowania współczesnego. Przykładem może być uwaga Rybickiego o tym, że prace takie jak słownik Mączyńskiego i gramatyka Statoriusa były pracami odosobnionymi, ponieważ

szerzej nie rozumiano i nie odczuwano potrzeby prac filologicznych nad językiem rodzimym, jak w ogóle nad językami nowożytnymi. Prace te miały się rozwinąć w następnym okresie (ibid.).

Ta negatywna opinia jest opinią przesadzoną, ponieważ z danych Heinza (1978: 95) wynika, że było zupełnie inaczej.

5.2. Pisząc o Historii nauki polskiej pod redakcją B. Suchodolskiego, chciałbym zadać powracające pytanie o to, czy historię nauki powinni pisać przedstawiciele opisywanej dyscypliny, widzący jej rozwój niejako od wewnątrz, czy też historycy 
uprawiający historię nauki, patrzący na tę dyscyplinę z zewnątrz. Moim zdaniem każde rozwiązanie ma swoje dobre i złe strony, jednak zdecydowanie opowiadam się za tym, aby każdy piszący znał wszystkie prace na temat historii swojej dyscypliny. Im więcej ujęć różnych problemów cząstkowych, tym lepiej dla całości powstającej pracy. Gdyby S. Urbańczyk uwzględnił istniejące wcześniej prace na temat historii filologii polskiej i językoznawstwa, być może inaczej podszedłby do problemu początków językoznawstwa w Polsce.

Przy tej okazji chciałbym zwrócić uwagę na nowe prace historyków, powstające w ramach specjalizacji, jaką jest historia nauki, gdyż można tam znaleźć wiele publikacji interesujących dla osób zajmujących się historią językoznawstwa. Na szczególną uwagę na pewno zasługuje monografia Złote lata polonistyki lwowskiej (1919-1939) Mariusza Chrostka (2016). Składa się ona $\mathrm{z}$ dwu części, z których pierwsza nosi tytuł Uczeni i ich osiagnięcia i ma charakter zdecydowanie biograficzny. Uczeni filolodzy zostali podzieleni na cztery grupy: historyków literatury polskiej, językoznawców polonistycznych, filologów klasycznych i nowożytnych oraz metodyków. Językoznawcom poświęcono wiele miejsca na s. 215-303. Wśród profesorów M. Chrostek przedstawił sylwetki takich uczonych, jak Kazimierz Nitsch, Henryk Ułaszyn, Tadeusz Lehr-Spławiński, Henryk Gaertner, Witold Taszycki, Zdzisław Stieber, Andrzej Gawroński, Jerzy Kuryłowicz i Maria Dłuska. W grupie asystentów przy katedrze języka polskiego i filologii słowiańskich znajdujemy sylwetki Stanisława Bąka, Władysława Kuraszkiewicza, Tadeusza Milewskiego, Stanisława Jodłowskiego, Franciszka Jakubowskiego, Zygmunta Rysiewicza, Stefana Hrabca i Stanisława Rosponda. Trzeba podkreślić, że Chrostek nie tylko pisze o ich pracy w Uniwersytecie Jana Kazimierza, ale także przedstawia początki ich kariery naukowej w innych ośrodkach akademickich oraz dalszą działalność naukową już po opuszczeniu Lwowa.

Osobno warto zaznaczyć, iż przygotowując swą monografię, Chrostek, który jest historykiem literatury, przeprowadził rozległą kwerendę w Państwowym Archiwum Obwodu Lwowskiego oraz w Centralnym Państwowym Historycznym Archiwum Ukrainy we Lwowie, co zasługuje na specjalne uznanie choćby z tego względu, że językoznawcy rzadziej odwołują się do źródeł archiwalnych.

W erudycyjnym wstępie autor zadał pytanie, czy można mówić o tym, że polonistyka lwowska była w okresie dwudziestolecia "niekwestionowanym liderem”. Odpowiedział na nie zaraz, stwierdzając, że „tego wykluczyć nie można”, ale później już do tego pytania nie wracał, choć lepiej by było, gdyby w podsumowaniu każdej części szukał argumentów przemawiających za tą tezą. Pamiętam, że jeszcze w latach 60. XX w. wśród studentów polonistyki UJ panowało przekonanie, że przed wojną polonistyka lwowska była najlepsza w kraju. Muszę jednak dodać, że zajęcia na polonistyce UJ prowadzili wówczas tacy profesorowie, jak: S. Jodłowski, M. Dłuska i W. Taszycki, w młodości związani z Uniwersytetem Jana Kazimierza i mówiący o nim $\mathrm{z}$ wielkim uznaniem.

Warto dodatkowo zauważyć, że w części wstępnej autor opisał Uniwersytet Lwowski u progu dwudziestolecia międzywojennego oraz rozwój katedr polonistyki 
oraz filologii z nimi powiązanych, co stanowi świetnie napisane, panoramiczne wręcz wprowadzenie do całej części pierwszej. W części drugiej o charakterze problemowym, zatytułowanej Środowisko polonistyczne. Ludzie i miejsca, dokonał Chrostek analizy bazy lokalowej, kadry nauczającej pod względem uzyskiwania stopni akademickich oraz jej statusu zawodowego i społecznego, a także sytuacji materialnej. Kolejne miejsca w tej analizie zajmują studenci, działalność zakładów naukowych, tematyka wykładów, ćwiczeń i seminariów, rola bibliotek w pracy polonistów, towarzystwa naukowe, jubileusze, akademie i inne uroczystości, profesorskie przyjaźnie i animozje. Okazały, gdyż liczący 637 stron, tom zamyka zakończenie, w którym autor omówił ostatnie lata Uniwersytetu Jana Kazimierza i exodus profesorów. Czy można się dziwić, że w środowisku polonistycznym mówi się o tej pracy z uznaniem? Na dowód przytoczę tylko trzy zdania z recenzji wydawniczej Mieczysława Inglota, której fragmenty znajdują się na czwartej stronie okładki:

Jest to praca pisana $\mathrm{z}$ rozmachem i ambicją ogarnięcia nie tylko obrazu polonistyki, ale także filiacji tej dyscypliny. [...] To swoistego rodzaju płyta na okazale zbudowanym grobowcu. [...] To zatem praca ważna dla kultury i znakomita warsztatowo.

Chciałbym tu także zwrócić uwagę na studia porównawcze, powstające $\mathrm{w}$ ramach historii nauki i będące poniekąd specjalnością tej dziedziny badań naukowych. Przykładem niech będzie numer specjalny „Prac Historycznych” z 2018 r., opublikowany w ramach „Zeszytów Naukowych UJ”. Numer przygotowany pod redakcją Marii Stinii i Tomasza Pudłockiego nosi tytuł $W$ kręgu historii nauki i oświaty. Uniwersyteckie środowiska filologów krakowskich i lwowskich, 1850-1939 (Stinia, Pudłocki 2018). Redaktorzy zawarli w nim dziewięć ciekawych artykułów porównujących środowiska neofilologów z Uniwersytetu Jagiellońskiego i Uniwersytetu Jana Kazimierza podczas niemal stu lat dziejów tych uczelni.

\section{Językoznawstwo stosowane i glottodydaktyka w historii językoznawstwa polskiego}

6.1. Jako językoznawca zajmujący się w dużym stopniu nauczaniem języka polskiego jako obcego, drugiego i odziedziczonego nie mogę nie wspomnieć o miejscu językoznawstwa stosowanego i glottodydaktyki w przyszłej historii językoznawstwa polskiego, gdyż w dotychczasowych opracowaniach syntetycznych poświęcano im bardzo mało miejsca albo wręcz je pomijano. Po raz pierwszy zwróciłem na to uwagę $\mathrm{w}$ artykule Miejsce glottodydaktyki w językoznawstwie polonistycznym (Miodunka 2018), w którym analizowałem m.in. hasła językoznawstwo stosowane i glottodydaktyka w Encyklopedii językoznawstwa ogólnego pod redakcją Kazimierza Polańskiego (EJO) oraz w Encyklopedii języka polskiego pod redakcją S. Urbańczyka (EJP). Napisałem w nim tak: 
[po sprawdzeniu obecności] obu interesujących nas terminów w Encyklopedii języka polskiego, stwierdzamy, że nie ma w niej ani terminu "językoznawstwo stosowane”, ani terminu "glottodydaktyka”. Fakt ten jest o tyle zaskakujący, że autorem interesujących nas haseł w EJO był Kazimierz Polański, współautor EJP i autor haseł z zakresu językoznawstwa ogólnego w EJP. Najwyraźniej zespół autorski EJP uznał, że albo hasła te nie odnoszą się do języka polskiego, albo nauczanie języka polskiego jako obcego jest zjawiskiem na tyle marginalnym, że nie zasługuje na osobne hasło w EJP (Miodunka 2018: 8).

Takie podejście do nauczania języka polskiego jako obcego jest zaskakujące, jeśli się zważy choćby długość tradycji nauczania cudzoziemców polszczyzny. Tymczasem wiadomo, że

tradycja nauczania języka polskiego jako obcego sięga początków XVI wieku, podczas gdy rozpowszechniona tradycja nauczania polszczyzny jako języka ojczystego odwołuje się do prac Komisji Edukacji Narodowej. Z tego stwierdzenia wynika bardzo ważny wniosek, że tradycja nauczania polszczyzny jako języka obcego jest o ponad 200 lat dłuższa niż tradycja nauczania jej jako języka ojczystego. To bardzo ważne spostrzeżenie, będące istotnym argumentem za tym, by przyznać glottodydaktyce polonistycznej bardziej liczące się miejsce w językoznawstwie polonistycznym (Miodunka 2016: 228).

$\mathrm{Na}$ inny aspekt tego samego zjawiska zwróciła uwagę Anna Dąbrowska w artykule Nauczanie polszczyzny jako języka obcego w historii języka polskiego (2018). Podkreśliła ona wyraźnie, że

Pierwsza gramatyka języka polskiego, napisana po łacinie dla obcokrajowców przez Francuza, Piotra Statoriusa-Stojeńskiego Polonicae grammatices institutio, powstała ponad dwieście lat wcześniej niż pierwsza gramatyka języka polskiego napisana przez Polaka dla Polaków (przez Walentego Szylarskiego w 1770 roku). [...] Przez dwa stulecia nie było gramatyk języka polskiego pisanych dla rodzimych użytkowników języka. Od pojawienia się pierwszego takiego opracowania w 1770 roku aż do dziś równolegle ukazują się zarówno te z przeznaczeniem dla obcokrajowców, jak i takie, których adresatami są rodzimi użytkownicy języka. Oba te nurty płyną obok siebie [...] (ibid.: 23-24).

Można by przypuszczać, że wydanie pierwszej gramatyki języka polskiego napisanej przez Polaka dla Polaków oznaczało nową epokę w przedstawianiu struktury polszczyzny, wolną teraz od sposobu widzenia naszego języka przez obcokrajowców. Tymczasem wcale tak nie było: „Gramatyka Walentego Szylarskiego oświeceniową wersją gramatyki Franciszka Mesgniena-Menińskiego” - taką tezę postawiła Wanda Decyk-Zięba (2019) w tytule artykułu opublikowanego w „Poradniku Językowym” w 2019 r. Porównawszy strukturę obu gramatyk, sposób objaśniania zjawisk językowych oraz podawane przykłady, autorka stwierdziła, że teza postawiona w tytule artykułu 
ma swoje uzasadnienie zarówno w układzie treści w obrębie rozdziałów i ich zawartości treściowej, jak i w doborze przykładów. Natomiast [...] różnice są powiązane zarówno ze zmianami zachodzącymi w systemie językowym, w rzeczywistości pozajęzykowej, jak i z rozwojem wiedzy o języku, z pojawieniem się nowoczesnych podręczników do nauczania języka łacińskiego (np. S. Konarskiego) i przeznaczeniem obu dzieł. [...] Szylarski korzysta z gramatyki Menińskiego w sposób krytyczny, dokonuje rewizji ustaleń teoretycznych swojego poprzednika, przedmiotem opisu jest polszczyzna współczesna. Trafił na gramatykę Menińskiego zapewne przypadkowo, ale miał niezwykłe szczęście, gdyż była to „jedna z najlepszych gramatyk polskich” (Jefimow 1970: 19) (Decyk-Zięba 2019: 111-112).

Dla dopełnienia obrazu stosunku językoznawców polskich do nauczania języka polskiego jako obcego chciałbym przytoczyć podsumowanie obecności gramatyk i podręczników do tego nauczania w pracach z zakresu historii języka, dokonane przez A. Dąbrowską (2018) w cytowanym wcześniej artykule. Po przeprowadzeniu szczegółowej analizy tego zagadnienia badaczka stwierdziła:

[...] przegląd istniejących historii języka polskiego pokazuje, że od lat osiemdziesiątych XIX wieku spojrzenie na tę historię ewoluuje. Jest to oczywiste, jeśli weźmie się pod uwagę czynnik czasu. Interesujące mnie odwoływanie się przez badaczy historii języka polskiego do dawnych opracowań przeznaczonych dla cudzoziemców uczących się języka polskiego jako obcego [dalej: JPJO - W.M.] nie pojawiało się u wszystkich autorów. Wynikało to prawdopodobnie z przyjętych przez nich założeń oraz - być może - z niepełnej znajomości tych źródeł, tym bardziej, że monograficzne opracowania poświęcone nauczaniu polszczyzny w miastach o mieszanej ludności niemiecko-polskiej zaczęły się ukazywać tuż przed II wojną światową (pierwsza w 1938 roku). Ponadto podchodzono do dziejów polszczyzny jako do dziejów języka ojczystego (narodowego), pomijając fakt, że przez kilka wieków był to język drugi dla części mieszkańców Rzeczypospolitej Obojga Narodów i jej lenn, a także dla pewnych kręgów mieszkańców krajów ościennych. Z analizy wspomnianych monografii dziejów języka polskiego wynika, że najobficiej ze źródeł przeznaczonych prymarnie dla cudzoziemców korzystał Z. Klemensiewicz, znający i wykorzystujący prace co najmniej dwudziestu autorów takich pozycji. Drugim z kolei badaczem jest B. Walczak, którego Zarys dziejów... również [...] zawiera informacje o nauczaniu JPJO cudzoziemców oraz o podręcznikach i gramatykach pisanych z przeznaczeniem dla nich (ibid.: 35-36).

Jak widać, Dąbrowska zauważyła dość ograniczone uwzględnianie przez historyków języka polskiego gramatyk i podręczników przeznaczonych dla cudzoziemców. Ten fakt tłumaczy możliwą nieznajomością opracowań historycznych oraz tym, że historia języka polskiego była przez wiele lat postrzegana jako historia języka ojczystego Polaków, z pominięciem innych mieszkańców polskich ziem i krajów sąsiednich, którzy również polszczyzną się posługiwali. Aby postawić sprawę jasno, postuluję, by przyszła historia językoznawstwa polskiego uwzględniała gramatyki 
i podręczniki przeznaczone dla wszystkich znających polszczyznę i używających jej w komunikacji, niezależnie od tego, czy byli oni Polakami, czy nie (por. Miodunka 2011). Informuję również, że pięćsetletnia tradycja nauczania polszczyzny jako języka obcego została dokładniej przedstawiona w Dydaktyce i metodyce nauczania języka polskiego jako obcego i drugiego Przemysława Gębala i Władysława Miodunki (Gębal, Miodunka, w druku).

6.2. Prowadzone dotychczas dyskusje i badania naukowe doprowadziły do powstania trzech gałęzi glottodydaktyki polonistycznej: dydaktyki polszczyzny jako języka obcego, drugiego i odziedziczonego. Najbardziej zaawansowana z nich jest dydaktyka języka polskiego jako obcego. Cały jej dorobek teoretyczno-metodologiczny oraz praktyczny powstały w latach 1950-2015 został podsumowany w monografii W.T. Miodunki Glottodydaktyka polonistyczna. Pochodzenie - stan obecny - perspektywy (2016). Dydaktyka polszczyzny jako języka odziedziczonego zaczęła się rozwijać o wiele później, bo dopiero po roku 2003, natomiast po roku 2010 powstały podstawowe prace takich badaczek, jak Ewa Lipińska i Anna Seretny (2012), Hanna Pułaczewska (2017) oraz Anna Żurek (2018), a także tom zbiorowy pod redakcją Juliane Besters-Dilger, Anny Dąbrowskiej, Grzegorza Krajewskiego i Anny Żurek (2016). Szybki postęp, jaki się dokonał w zakresie dydaktyki języka odziedziczonego, zawdzięczamy w dużym stopniu badaniom przeprowadzonym w Niemczech, opartym na solidnych podstawach metodologicznych i bogatym materiale. Bardzo dobrze się stało, że w prace te zaangażowała się J. Besters-Dilger, europejski autorytet w zakresie analizy języków słowiańskich jako odziedziczonych, gdyż dzięki temu opracowania polskie mają szansę zaistnieć w kręgu badań światowych.

6.3. Jeszcze później, bo dopiero około roku 2010, zaczęły powstawać naukowe i dydaktyczne prace związane z nauczaniem języka polskiego jako drugiego. Glottodydaktyczny dorobek w tym zakresie był rozproszony i dlatego bardzo dobrze się stało, że jego podsumowanie ukazało się w monografii P. Gębala Podstawy dydaktyki języka polskiego jako drugiego. Podejście integracyjno-inkluzyjne (2018). Dzięki tej pracy glottodydaktyka polonistyczna może stać się partnerem dla zaawansowanych badań socjologicznych, edukacyjnych i psychologicznych prowadzonych dotąd w Polsce. Powinna też zostać uwzględniona jako część językoznawstwa polskiego w przyszłej jego historii, niezależnie od tego, czy historia ta będzie pisana przez językoznawców, czy przez historyków. 


\section{Literatura}

Besters-Dilger J., DĄвrowska A., Krajewski G., Żurek A. (red.), 2016, Utrata i odzyskiwanie języka polskiego. Językoznawcze i glottodydaktyczne aspekty niepełnej polsko-niemieckiej dwujęzyczności, Pruszków k. Łasku.

Chrostek M., 2016, Złote lata polonistyki lwowskiej (1919-1939), Rzeszów.

Czelakowska A., 2020, Uczeni i ich losy... - Mirosław Skarżyński jako badacz dziejów polskiej lingwistyki, „LingVaria” nr 2 (30), s. 177-191, https://doi.org/10.12797/LV.15.2020.30.14.

Czelakowska A., Rak M., 2019, Profesor Mirosław Skarżyński, 1952-2019, „LingVaria” nr 2 (28), s. 7-10, https://doi.org/10.12797/LV.14.2019.28.oo.

DĄBRowska A., 2018, Nauczanie polszczyzny jako języka obcego w historii języka polskiego, "Język Polski” XCVIII, s. 22-41.

DECAUX E., 1968, Il y a quatre cents ans paraissait sous la signature d'un Français la première grammaire polonaise, „Revue de l'Ecole Nationale des Langues Orientales” 5, s. 153-162.

Deсук-Zı̨̨вA W., 2019, Gramatyka Walentego Szylarskiego oświeceniową wersją gramatyki Franciszka Mesgniena-Menińskiego, „Poradnik Językowy” nr 10, s. 104-113.

EJO: K. Polański (red.), Encyklopedia językoznawstwa ogólnego, wyd. 2 popr. i uzup., Wrocław - Warszawa - Kraków 1999.

EJP: S. Urbańczyk (red.), Encyklopedia języka polskiego, wyd. 2 popr. i uzup., Wrocław Warszawa - Kraków 1994.

GĘBAL P.E., 2018, Podstawy dydaktyki języka polskiego jako drugiego. Podejście integracyjno-inkluzyjne, Kraków.

GęBAl P.E., Miodunka W.T., w druku, Dydaktyka i metodyka nauczania języka polskiego jako obcego i drugiego, Warszawa.

Heinz A., 1978, Dzieje językoznawstwa w zarysie, Warszawa.

Jefimow R., 1963, Stojeński i Volckmar. Przyczynek do dziejów polskiej gramatyki, „Język Polski” XLIII, s. 218-230.

Jefimow R., 1970, Z dziejów języka polskiego w Gdańsku. Stan wiedzy o polszczyźnie w XVII wieku, Gdańsk.

KlemensiewiCz Z., 1974, Historia języka polskiego, wyd. 2, Warszawa.

Lipińska E., Seretny A., 2012, Między językiem ojczystym a obcym. Nauczanie i uczenie się języka odziedziczonego na przykładzie chicagowskiej diaspory polonijnej, Kraków.

Miodunka W.T., 2011, Między etniczno-genealogicznym a kulturowym rozumieniem narodu. O potrzebie historycznojęzykowych badań polszczyzny jako języka obcego i drugiego, „LingVaria” nr 1 (11), s. 179-204.

Miodunka W.T., 2016, Glottodydaktyka polonistyczna, Pochodzenie - stan obecny - perspektywy, Kraków.

Miodunka W.T., 2018, Gramatyka języka polskiego Statoriusa ukazała się 450 lat temu. Refleksje o jej znaczeniu dla historii polskiego językoznawstwa, „Poradnik Językowy” nr 10, s. 9-24.

PuŁaczewsKa H., 2017, Wychowanie do języka polskiego w Niemczech na przykładzie Ratyzbony. Dwujęzyczność dzieci z perspektywy rodziców, Łódź.

Ryвicki P., 1970, Odrodzenie, [w:] B. Suchodolski (red.), Historia nauki polskiej, t. I, Wrocław - Warszawa - Kraków, s. 361-375.

SĘKowsкA E., w druku, List jako źródło do historii polskiego językoznawstwa, „Białostockie Archiwum Językowe". 
SKARŻYŃski M., 1994, Części mowy i ich kategorie w gramatykach polskich XIX i XX wieku (1817-1938), „Rozprawy Habilitacyjne UJ” nr 281, Kraków.

SKARŻYŃSKI M., 2001, W kręgu gramatyk polskich XIX i XX wieku, Kraków.

SKarżYŃski M., 2019, Geneza i początki Studium Słowiańskiego UJ, „LingVaria” nr 1 (27), s. 11-33, https://doi.org/10.12797/LV.14.2019.27.01.

Statorius P., 1568/1980, Polonicae grammatices institutio, Cracoviae 1568. Nunc iterum ed. R. Olesch, „Slavistische Forschungen” 26, Köln - Wien (wyd. fototypiczne).

Stinia M., PudŁocki T. (red.), 2018, W kręgu historii nauki i oświaty. Uniwersyteckie środowiska filologów krakowskich i lwowskich 1850-1939, „Zeszyty Naukowe Uniwersytetu Jagiellońskiego. Prace Historyczne” nr 145, z. 2, Kraków.

SuchODOLSKi B. (red.), 1970a, Historia nauki polskiej, t. I, Wrocław - Warszawa - Kraków.

Suchodolski B., 1970b, O powszechnej i polskiej historii nauki, [w:] idem (red.), Historia nauki polskiej, t. I, Wrocław - Warszawa - Kraków, s. VII-LXXI.

Urbańczy K S., 1993, Dwieście lat polskiego językoznawstwa (1751-1950), Kraków.

WalczaK B., 1995, Zarys dziejów języka polskiego, Poznań.

Zwoliński P., 1956, Gramatyki języka polskiego z XVII w. jako źródło poznania ówczesnej polszczyzny, „Poradnik Językowy” nr 7, s. 251-26o, nr 8, s. 310-321, nr 9, s. 356-369.

Zwoliński P., 1972, Pionierzy komparatystyki slawistycznej XVI wieku, [w:] Prace na VII Międzynarodowy Kongres Slawistów w Warszawie 1973. Językoznawstwo, „Z Polskich Studiów Slawistycznych”, seria 4, „Językoznawstwo”, Warszawa, s. 336-344.

ŻUReK A., 2018, Strategie komunikacyjne osób dwujęzycznych. Na przykładzie polszczyzny odziedziczonej w Niemczech, Kraków.

\section{Reflections on the Conception of the History of Polish Linguistics Summary}

The author explains his reason for taking up the topic by recalling his discussions with prof. Mirosław Skarżyński and encouraging him to prepare a publication in which he would present his conception of the history of Polish linguistics. Prof. Skarżyński will not write this paper any more, so this author decided to present his own reflections on the matter. He begins with the first grammar of Polish, Polonicae grammatices institutio, published in 1568 by a Frenchman Piotr Statorius-Stojeński, for foreigners who wish to learn the language. He presents the work against the European background, and shows that it belongs to the great European movement of the $16^{\text {th }}$ century, of preparing descriptions of contemporary languages. This author proposes that the publication of Statorius' grammar, and of Jan Mączyński's Latin-Polish dictionary (1564), can be considered the actual beginnings of Polish linguistics. In relation to S. Urbańczyk who tied those beginnings to year 1751, this author moves the date nearly 200 years back. He also refers to the opinions of historians of science. The paper concludes with remarks on the place of applied linguistics and glottodidactics in Polish linguistics. 